\title{
Inflação: Seus Problemas e Soluções
}

\section{J. Lúcio Bittencourt}

$A$ inflação com tôdas as suas conseqüências, tem sido um dos maiores males que já assolaram o Brasil, sem que seja encontrado o remédio seguro para curá-lo.

O autor, com oportunidade, procura abordat o assunto, relacionando inicialmente os erros cometidos, em sua opinião, pelos que têm procurado enfrentar o problema, para, afinal, apresentar uma série de sugestões sôbre a maneira de resolver as dificuldades da atual conjuntura econômica do Pais.

Algumas dessas sugestões, principalmente a apresentada para a reformulação agrária, com a constituição de uma Comissão paritária, composta de representantes do Executivo, Judiciário e Legislativo, são aproveitáveis e merecem estudo detalhado.

\section{I - INFLAÇÃO NÃO É CAUSA - É EFEITO}

C

OSTUMA-SE citar a inflação como a causa principal, senâu a única, que está levando o País de roldão às mais catastróficas conseqüênciàs econômicas, financeiras e sociais.

E' a inflação a justificativa sempre utilizada para todo êsse descalabro que aí está e a panacéia empregada, sem constrangimentos, a mancheias, para transformar, aos olhos do Povo, erros profundos, dolosos e culposos, em salutares soluções e em alviçareiras esperanças de salvação.

E, de tal modo conseguiu-se deformar a mentalidade brasileira com êsse martelar de tôdas as horas, todos os momentos e tôdas as coisas, que hoje só raciocinamos e fazemos previsões em têrmos de inflação e o País está sendo, aos poucos dominado solertemente por verdadeiro pânico inflacionário. 
Urge, assim, modificar e transformar tal mentalidade, errôneamente firmada em bases falsas, sob pena de submergirmos, sem apelação, no caos total.

Faz-se mister, urgentemente, ganhem principalmente as cúpulas, nova orientação alicerçada na verdade e na exata realidade, se convencendo do lamentável equívoco em que estão mergulhadas, para partirem para nôvo equacionamento do problema brasileiro, alcançando uma solução mais satisfatória e justa para todos.

Não queremos, com isso, dizer que não haja inflação no Brasil. Não! Apesar de reconhecermus que, em determinadas ocasiões e sob determinados aspectos especiais, poderíamos afirmar o contrário.

O que sustentamos convictamente é, isso sim, que a inflação não é a causa de nossos males. E não é causa porque, apesar de apregoada e combatida como tal, mesmo pelos melhores e mais lúcidos técnicos, é ela, antes de tudo, simplesmente, um efeito: uma conseqüência.

Quando muito, será um subefeito: uma subconseqüência.

Causa, nunca!

Ora, se a inflação brasileira é uma conseqüência, como se pretende atingir a resultados satisfatórios, combatendo-a diretamente e relegando-se a causa e os motivos que a deterninam?

Dirão muitos, principalmente os executores e planejadores da politica econômico-financeira do Govêrno, que não desconhecem a inflação como efeito e que, ao invés do que afirmamos, têm procurado vencê-la combatendo a causa e não o efeito.

Será?

Os fatos aí estão.

Vimos e continuamos a ver Ministros de Fazenda e grupos meritórios de financistas, planejadores econômicos de primeira linha, técnicos do que de melhor existe, combaterrdo o efeito inflação, ao contrário do que determinam e ensinam os mais rudimentares estudos de economia e finanças: o combate à causa dit inflação.

\section{Não é verdade?}

Então vejamos: que fêz um dos últimos Ministros da Fazenda do Brasil? - restringiu o crédito; retalhou o orçamento em verbas vitais; deixou de pagar credores; tomou, enfim, uma série de medidas violentamente restritivas e; por fim, anunciou o contrôle da inflação.

Será essa orientação uma luta contra a causa? Ou será, muito ao contrário, um estimulante ao motivo e uma ação contra o efeito? 
Foram abruptamente, violentamente, comprimidas em um saco, as fôlhas da inflação, mas as raizes da àrvore, deixadas livres, regadas e adubadas.

Momentâneamente, na aparência, a inflação fôra contida e dominada.

Mas, a árvore, estimulada em seu viço, forcejava e esforçava-se por libertar as fôlhas cativas e o que não poderia deixar de acontecer, ocorreu também de maneira abrupta e violenta : o saco rompeu-se : as fôlhas libertaram-se : a inflação entrou em ritmo vertiginoso: o pavor e o pânico embalançaram a tranqüila convicção das cúpulas.

sua causa.

Por que? - Porque se combateu ao efeito inflação e não à

Entender de forma diferente, é confundir causa com éeito e enveredar pelo êrro, sem alternativa e com os mais catastróficos resultados.

Já compararam a inflação brasileira a uma panela de água a ferver em fogo intenso. Se não houver diminuição na intensidade do fogo, o vapor d'água sempre em crescente formação e contido no espaço restrito, kará, dentro em breve, voar a tampa da panela.

O fogo é a causa da inflação. A água, o subefeito. $O$ vapor d'água, o efeito.

O fogo é o desequilibrio estrutural. A água, o momento social brasileiro, em efervescência. $O$ vapor d'água, o caminho para a
subversão e a ilegalidade.

Se o fogo não fôr amenizado, a água continuará a ferver. com redobrado impeto, se transformando, tôda ela, em vapor
d'água.

Nossos técnicos, no entanto, pareceram e parecem ignorar que o fogo é que deve ser combatido, não com a paralisação das emissões; o racionamento das verbas; o corte e a restrição de créditos. Confundiram fogo e água e aumentaram o vapor d'água pregando calotes; estagnando o desenvolvimento do Pais; aumentando o desemprêgo; elevando o custo de vida, através de medidas tomadas pelo meio; lançando o Povo em maior miséria e a Nação em maiores dificuldades.

Quantas e quantas fábricas foram paralisadas em decorrência de medidas restritivas que, até hoje, ainda se refletem na vida nacional? Quantas e quantas familias foram lançadas ao desespêro? Quantos e quantos trabalhadores ficaram desempregados? Quantas e quantas falências foram decretadas? $\mathrm{E}$, para coroar tudo, em quanto caiu a taxa de desenvolvimento do País?

E, tudo isso, para que? Com que fim?

Para se dizer que a inflação foi contida e dominada?

Os resultados, hoje, ai estão: a tampa da panela só a muito custo está sendo contida em selı lugar. 


\section{II - O QUE É PRECISO FAZER}

Antes de mais nada, precisamos verificar quais as causas reais que determinaram o desencadeamento do atual surto inflacionário.

São elas as mais variadas, desde as fundamentais, representadas pelos violentos desequilibrios estruturais, motivados pela descontrolada e atabalhoada transição verificada, principalmente, no decênio 1950-1960, quando abandonamos a base agropecuária que norteava a nossa economia, para ingressar decidida e vigorosamente na fase da industrialização.

Essa transição ex-abrupto, ocasionando o deslocamento das populações rurais para a cidade, em busca de melhores condições de vida, determinou que se verificasse vertiginosa queda na produção rural, enquanto, no asfalto, foram aumentadas as necessidades de consumo, pela adição de novas bôcas.

A oferta passou, assim, a ser menor que a procura, no que tange a produtos alimentícios e os pratos da balança se desencontraram bruscamente.

Quebrado o equilibrio, passou-se à especulação, à fraude, ao açambarcamento, com cada qual procurando usufruir o máximo, com o mínimo de esforços: as fortunas se multiplicaram da noite para o dia; as mentalidades de deformaram: os assalariados foram mergulhados na incerteza e na miséria.

Se, em 1952, já nos limiares da catástrofe que se avizinhava, ao invés de ser criado um órgão contensor de preços como a COFAP, fôsse amparado enèrqicamente o campo, dando ao trabalhador rural motivo para dêle não se afastar, possivelmente tudo teria sido evitado.

Mas, não: Agravamos a situação rural; relegamos a agropecuária e disconhecemos que seres humanos, nossos irmãos, mereciam melhor vida, menos sacrificada e mais condigna, ao contrário daquela a que foram arrastados.

Foi esquecido, na ocasião, que o amparo ao trabalhador e aos produtores rurais não deveria ser tido como um favor, mas sim como a única solução para o desenvolvimento e a vitalidade da própria indústria e que, agindo com aquela imprevidência, estávamos nos condenando a todos nós, ao futuro que é a realidade de hoje.

$E$ a verdade é que, com o despivel entre a oferta e a procura ainda relativamente suportável, a atuação daquele organismo, combatendo o intermediarismo ganancioso que começava a tomar corpo, foi satisfatória e resolveu momentâneamente o problema.

Mas tal desnivel foi se acentuando cada dia que passava. A produção agropastoril, mais e mais, era insuliciente para atender aos reclamos de consumo e todos começaram a verificar 
que os preços não mais podiam ser controlados e, naquela conjuntura, a COFAP passou a representar um mal necessário.

Dai para diante, quando se procurou corrigir a deficiência, com importações de produtos alimentícios, mergulhamos definitivamente no vácuo e, aos trambulhões, estamos caindo até agora. Os meios rurais, definhando: os trabalhadores de campo, morrendo à mingua: a produção agricola, baixando mais e mais: os produtores, entregues à própria sorte e ao arbitrio dos intermediários.

Dêsse desequilibrio entre o campo e o asfalto, gerou-se tudo o mais: as subvenções governamentais a entidades deficitárias: - endividamento no exterior: as emissões maciças para suprir deficits: a inflação: o desequilibrio orçamentário: o aumento ver tiginoso do custo de vida: o empobrecimento sempre maior dos assalariados: o enriquecimento desumano dos que vivem do aumento de preços e das especulações.

Como corrigir-se, agora, o êrro da falta de planejamento estrutural, já em fase deveras avançada, em que o problema atinge foros de grande relêvo e desafia estudos, doutrinas e orientações, inutilizando esforços e tornando inócuas as menores tentativas para cercear e conter a voragem inflacionária?

Temos que reconhecer, na atual conjuntura, ser a sua esquematização, sumamente dificil, tornando-se obra ciclópica encontrar o caminho para uma solução plausivel e exeqüivel.

Por isso mesmo, exige-se mais que a argúcia dos técnicos, porque exige-se a serenidade e segurança para a execução de medidas muitas vêzes drásticas, impopulares e, aparentemente, injustas.

A nosso ver, o controle da inflação, só será possivel se o govêrno resolver arcar, de forma decidida e resolutamente, sem tergiversações e ambigüidades, com os ônus iniciais das medidas
que se impõe sejam tomadas.

Tais medidas, a serem tomadas em diversas fases e que nós consideraríamos como de prazo imediato; de curto; médio e longo
prazo, seriam:

\section{A prazo imediato}

Decretação do congelamento de taxas, impostos, tarifas, salários e preços em geral, pelo prazo de noventa dias.

Tal medida visa conter, por aquêle periodo, artificialmente. o custo de vida, de forma a permitir o estudo e preparação, para entrarem em execuçâo conjuntamente, logo após ao término do referido espaço de tempo, das demais medidas consideradas de
curto prazo e que seriam: 


\section{A curto prazo}

a) atualização das taxas cambiais dentro da realidade dos fatos e decretação de novos preços dos produtos e bens importados;

b) atualização das tarifas ferroviárias, maritimas, rodoviárias e aéreas, com a cobrança de preços justos aos usuários e a suspensão da subvenção governamental;

c) suspensão de subvenções de tôdas e quaisquer ordens ou títulos, inclusive as pagas a produtores, com a atualização dos preços respectivos, para o usuário ou consumidor;

d) reescalonamento dos pagamentos das dividas externas;

e) reestudo de todos os impostos e taxas, de forma a propiciar melhor equilibrio entre a receita e a despesa;

f) atualização do preço de compra de ouro pelo Tesouro, considerando-se os preços vigentes no mercado mais uma sobretaxa de até $5 \%$;

g) criação de um Ministério Extraordinário de Arrecadação, com rigorosas instruções e perfeito aparelhamento, para a execução de medidas dirásticas visando a coibir a evasão de impostos;

h) aparelhamento da SUNAB, para dedicar-se com êxito ao contrôle dos preços, especialmente daqueles referentes a gêneros, artigos e serviços de primeira necessidade;

i) reestruturação dos escritórios comerciais no Exterior, de forma que os mesmos sejam mantidos e custeados sem ônus para o govêrno, com rendas decorrentes de taxas a serem cobradas aos exportadores;

j) extinção de tôdas as demais representações do Brasil no Exterior, exceto as diplomáticas, cujas estruturas também devem ser revistas, de forma a não exorbitarem nos gastos de manutenção;

k) designação de comandos de exploração e fiscalização de riquezas do subsolo, para a procura de jazidas e minas de metais e pedras preciosas, com o concurso das Fôrças Armadas e Ministério de Minas e Energia;

l) criação de pelotões agrários no Ministério da Agricultura com o concurso do Exército, para a instalação de núcleos agropecuários e escolas modelos;

$m$ ) adoção de nova moeda, a par com o dólar no câmbio manual;

n) facilidades de financiamento a novos empreendimentos privados, que concorram para o desenvolvimento do País;

o) decretação de novos níveis de salário-mínimo, consideradas rigorosamente as necessidades para uma vida condigna; 
p) uniformização dos salários pagos a empregados em Entidades de Economia Mista, Autarquias, inclusive maritimas, e funcionários públicos, com a instituição do salário-móvel para pagamento de tais servidores;

q) estudo com rigorosa obediência à realidade, dos novos preços de gêneros, artigos, produtos e serviços.

Tais medidas, a serem postas em execução logo após o vencimento do prazo de noventa dias relativo ao congelamento de preços já mencionado, visam desafogar o Govêrno das dificul. dades que o obrigam a emitir papel moeda quase diàriamente (alineas a a e) tornando os preços rigorosamente reais.

A compra de ouro pelo Tesouro, com um ágio de até $5 \%$, tem por fim evitar o contrabando e a evasão de ouro que se verifica de forma violenta no País, e concorer para o fortalecimento da nossa moeda.

Nas alineas $g$ a $j$, são propostas medidas administrativas que visam diminuir as despesas de administração e pessoal de nossas representações no Exterior, que acarretam gastos inusitados para o País.

Com as medidas mencionadas nos itens $g$ e $h$, tivemos por mira refrear e diminuir a evasão constante e crescente de impostos e, também, cercear a ação dos especuladores, que poderão prejudicar fundamentalmente o presente planejamento.

O aumento de nossas reservas, que podem, por si só, fazernos sair da crise atual, poderia também ser conseguido com a maior e melhor exploração de nossas riquezas do subsolo e a fiscalização idônea de sua circulação. Na alinea $l$ propomos, portanto, a designação de comandos com o concurso das Fôrças Armadas e Ministério das Minas e Energia, com aquela finali-
dade.

O aumento de nossa produção agropecuária, dependente de uma reforma agrária equilibrada, a que não deve faltar a assistência governamental ao homem rural, poderia ser conseguido com o concurso maior do Exército, devidamente entrosado com o $\mathrm{Mi}$ nistério da Agricultura. Deveria, mesmo, ser exigido, para a consumação da distribuição de terras aos trabalhadores rurais, um estágio dos mesmos nos núcleos ou escolas agropecuârias, onde poderiam, a par com a instrução agricola, aprender as primeiras
letras.

Tôdas zs medidas citadas, complementam-se com a adoção de nova moeda, mais forte e menos desmoralizada, que evitará, principalmente, despesas sempre maiores com as volumosas e crescentes emissões de papel moeda e com a decretação de novos niveis salariais e novos preços, o que é providência inevitável.

Restam, agora, as medidas a médio e longo prazo. 


\section{A médio prazo}

a) efetivação, mediante esfôrço conjunto do Congresso e do Executivo, das reformas estruturais que se fazem necessárias, como sejam: administrativa; bancária; fiscal; agrária: urbana; eleitoral; de ensino e judiciária;

b) reformas e atualizações de códigos e Leis, para adaptá-los à realidade brasileira;

c) instituição do serviço militar agrícola, com o desdobramento do atual serviço militar obrigatório, em seis meses de serviço agrícola e seis meses de serviço militar.

Sôbre as reformas básicas nada de nôvo diriamos, afirmando que são urgentes e inadiáveis, sendo cada dia de retardamento na efetivação das mesmas, um dia a mais na caminhada empreendida pelo Brasil, em busca de sua emancipação.

O patriotismo de nossos legisladores, que não é maior nem menor do que o dos membros do executivo, que conhecem profundamente o problema, por certo há de permitir que, sem radicalizações ideológicas, as reformas sejam devidamente equacionadas.

Para tanto, é necessário, apenas, bom senso e patriotismo, propiciando os entendimentos entre as diversas correntes, para constituição de uma comissão paritária, com igual representação do Legislativo, Executivo e Judiciário e com podêres para projetar e estudar as reformas básicas que se fizerem necessárias.

Da mesma forma, poderia ser procedido com respeito à reforma dos códigos e atualização de leis.

Quanto à instituição do serviço agrícola, com a divisão do atual serviço militar em duas etapas, pensamos ser providência altamente vantajosa e mais um serviço relevante a ser prestado pelo Exército Brasileiro.

Todos sabemos o exodo que se verifica no campo, tendo por motivo a prestação, pelos jovens, do Serviço Militar obrigatório. O ruricola, vivendo uma vida miserável e amargurada, sujeito a tôdas as espécies de doenças, abandonado e maltratado, encontra no Serviço Militar uma válvula de escape para fugir às suas agruras. Vem para o asfalto, presta a sua obrigação e, quando dá "baixă", aqui fica, muitas vêzes para engrossar a fileira dos desocupados e pedintes.

Se conseguíssemos determinar um fato contrário, levando ao campo, após o período de instrução militar, os jovens convocados. para receberem instrução e orientação agricola, em escolas e núcleos agropecuários do Exército, além de estarmos aumentando a produção do campo, o que nos é tão necessário, estaríamos dando 
aos futuros reservistas oportunidade de conhecerem os meios de vencerem as dificuldades rurais e propiciando-lhes motivos para povoarem o hinterland.

\section{A longo prazo}

Reforma da mentalidade brasileira, mediante uma segura educação de nossas gerações nas sendas do bem e da justiça, com a abominação de tôdas as formas de corrupção.

Hoje, o que vemos, em razão do enfraquecimento moral causado, também, em grande parte, pela inflação, é o amolecimento dos jovens nos estudos e no trabalho. Os exemplos das inversões de valores, com o prêmio ao mais fraco e menos capaz. dos corruptos e peculatários, se sobrepondo aos honestos e bem intencionados; dus que, sem trabalhar, se locupletam à custa dos que labutam às vêzes de sol a sol; é muito forte para deixar de ser seguido pelas gerações em formação.

Precisamos principiar combatendo, com tôdas as nossas fôrças, com a garantia de não sermos nós os acusados, tal anomalia na vida brasileira, a fim de que os jovens sintam razão e motivo para estudar e trabalhar.

Ao mesmo tempo, com tal exemplo e a par com êle, precisamos mostrar-lhes as vantagens de praticarem o bem e amarem a sua Pátria, incutindo-lhes o sentimento de aversão à corrupção, à fraude, à desonestidade e a tudo o que possa prejudicar o bem comum e o interêsse pátrio.

Será, em última instância, se nada mais fôr feito, essa reforma da mentalidade nacional, o maior serviço que poderá ser prestado, pelas củpulas, à Nação Brasileira.

Mas, se afinal nada fôr feito, não teremos que temer pelo futuro. O Gigante chagado por saques de tôda espécie; ulcerado pela falta de amor da grande maioria de seus filhos; sangrando e sofrendo, vírima da disputa, da incúria, da desídia, do dolo e da má-fé, ainda encontrará fôrças, contra tudo e contra quase um prazo surpreendentemente curto. 